\title{
Forgetting to Remember Now and Then: AIDS, Memory and Homosexuality in André Téchiné's Les Témoins (2007)
}

\author{
MURRAY PRATT
}

Rather than offering an official history of the early years of HIV and AIDS in France, André Téchiné's 2007 film Les Témoins, set in 1984-1985, focalizes this timeframe through the attention it gives to a tightly demarcated group of friends, each of whom is brought into contact with the effects of the virus. Sarah (Emmanuelle Béart) and her partner Mehdi (Sami Bouajila) begin the film as new parents, and the opening scenes depict their friendship with Adrien (Michel Blanc), who is a doctor. Adrien encounters a younger man, Manu (Johan Libéreau), who is introduced into the group; the film charts the group's evolving relations with him as he develops AIDS and describes the impact of his death on their lives. It is this traumatic encounter that shapes their interactions with each other, and provides the experiential lens through which the phases of the national experience of HIV and AIDS awareness in France is revisited, as indicated by the choice of chapter headings that divide the film into three periods ("Les Beaux Jours", "La Guerre" and "Le Retour de l'éte"). Moreover, the narrative voiceover that frames the unfolding story of Manu's arrival within the group and his impact on its members is gradually revealed to belong to Sarah, who is effectively engaged in writing Manu's story after his death, signalling the film's status as recollection, or témoignage. Transcribing and contextualizing the tapes he leaves behind after his death, Sarah reveals herself only gradually as the narrator, archivist and author of the story that she and her entourage, with the exception of Manu, survive. After Manu's death, with the narrative position now explicit, Sarah is faced with a struggle that potentially threatens the film's own viability, as she is shown persisting in her work of transcription and reconstitution, despite the opposition of Mehdi, her husband and Manu's lover, who would rather move on, forget, or erase the memory of that story. Remembering the impact of AIDS, then, emerges as a fraught enterprise in itself, one that is implicated in personal histories that affect which aspects of the struggle against the virus are revisited by its witnesses. The film partially attends to the politics of AIDS activism by its foregrounding of the character of Adrien and his increasing involvement in campaigning after Manu's death. At the same time, however, Les Témoins sets up a narrative framework that positions HIV and AIDS as an experience that is primarily 
retrieved and understood through its impact on private lives and relationships. In doing so, it recalls Manu's illness, and Adrien's activist work, within a framing and mediating drama about people who are touched by, but survive, the epidemic, raising questions about whose voice is, or can be, retained within processes of rememoration.

Within the context of France's waning engagement with AIDS activism, together with what is increasingly posited within dominant cultural discourse as a normalization of homosexuality, this article will consider Les Témoins in terms of its dominant narrative tension between forgetting and remembering. For, casting an eye back to the mid-1980s to witness the moment that AIDS entered the country's consciousness, and as suggested by the trope of witnessing in its title, this is a film that positions itself as a carefully constructed tribute to those first affected, providing a potential national space for commemoration and recognition of the important roles played by gay men and the medical establishment in bringing the crisis to people's attention. However, as I will argue, the structure of the film, in particular its hesitation between a mediated account and openness to multiple viewpoints diverts attention to the personal drama experienced by its heteronormatively positioned couple, replicating a national tendency to regulate homosexual desires within Republican values and atomise the experience of gay men.

To understand the extent to which these issues remain unresolved, and are perhaps unresolvable, in both the national consciousness and in Les Témoins, this article will first contexualize the film within historical and emerging debates about the role of French cinema in relation to AIDS. It does so by showing how the familial focus and inattention to gay community in Les Témoins reveal, retrospectively, concerns about how to measure homosexuality alongside normative reproductive heterosexuality, and a continued anxiety about the possibility of gay community within France. To the extent that the commemorative process in the film is firmly anchored within a structure that positions the drama at one remove from the direct experience of HIV and AIDS, I argue that it replicates, rather than queries, the national tendencies of the 1980 s that led to an allocation and attribution of both value and urgency within normative, Republican contexts. With reference to a text dating from the period depicted, I will then advance an alternative model of retrospectivity, as detailed in René Scherer's preface to a text by Guy Hocquenghem, one capable of unfolding the past within the present in ways that avoid repeating the mistakes of history. Measured alongside other films of the mid-2000s, Téchiné's Les Témoins, I will argue in my conclusion, misses an opportunity to deploy the kinds of queering tactics Scherer discovers in Hocquenghem's more literary attempt to imagine a dynamics capable of opening up rather than closing off France's early experience of AIDS. 


\section{Competing attentions}

In keeping with much of the director's auvre, and functioning in some ways as a film à thèse, it is through an exploration of rival masculinities that this production opens up potentially competing perspectives on its meanings rather than closing them down to one unitary interpretation. The witnesses are, after all, defined as plural, and Sarah's recollection of Manu, the sense that she gives to his life, is by turns frustrated and assisted, then collectively composed, by Mehdi and Adrien. The different relationships that each of these male characters establish with Manu, in keeping with Téchinés interest in exploring competing male identities, provide Les Témoins with much of its dramatic tension. Adrien's initial friendship with the youth, though described and visually rendered through the choice of activities they undertake as platonic, becomes the basis for a jealous rivalry only after Manu and Mehdi start having sex with each other. In a central sequence of three debate/ confrontation scenes, arguments break out between Mehdi and Adrien, with the visual contrast between the younger, sexually aware, beur protagonist and the older, bespectacled professional highlighted. The narrative rationale for their disputes is a struggle over Manu, however, rather than an unproblematic transposition of heterosocial codings, the scenes are mined for the competing value systems and the meanings surrounding both homosexuality and AIDS that are brought to bear on the situation by these two differently positioned men. For Mehdi, Adrien's proprietary attitude to Manu represents "[s] on partage dans le ridicule", a failure in comparison with his own sexual conquest. Dismissing Adrien as a stereotypical pédé with a "bouquet de fleurs dans le cul", Mehdi in turn is characterized as a predator, exploiting Manu's vulnerability without really caring for him.

As Manu becomes progressively ill, Adrien's role as his primary carer is also challenged by Mehdi, who sees him as profiting from the youth's condition, to the extent that he tells him "C'est la mort qui te fait bander". It is worth pointing out, however, that rather than being simply the passive object of their competing affections, Manu himself, even as his illness begins to affect his appearance, abilities and outlook, is seen to acquire autonomy beyond this struggle for his affections, or ownership, as he takes an increasingly active role within this clash of value systems. The choices he makes concerning which of the men he wishes to see, how, and when, structures much of the middle section of the narrative, underlined by the independence he exercises in other ways (for example, buying a gun and the potential control over his own destiny that this implies, or deciding to revisit the cruising area as he approaches death rather than attend his sister's performance).

The nuanced relational field in Les Témoins, then, constitutes a potential proliferation of the range of possible attitudes to the issues raised in the film. Adrien's and Mehdi's opposing views, each "justifiable" within the purviews afforded them by their life experience, hint at a range of possible testimonies: in the first instance, a focus on the channeling of energies towards medical and political activism that led to the establishment of the campaigning group, AIDES; in the second, a bisexual 
ambivalence that could be seen as questioning entrenched positions that deny or erase otherness within a masculinist and heterosexual economy of the self. Yet, the objective camera of Téchiné that opens up access to such different viewings is, at the same time, circumscribed by the retrospective frame of the story's recollection.

For, in order to activate competing vectors of memory, Les Témoins is required to "forget" its pretext, the voiced narrative position whereby Sarah's memory and transcription of Manu's tapes are responsible for structuring all that it recalls. Insofar as her writing desk is gradually revealed to be the film's generating matrix, her role in ultimately giving sense to its structuring debates is indissociable from its affective charge. Her part is to grieve, but equally to fear (for her own health and for that of her partner) and suffer (marital strife, the risk of distraction from her baby, confusion about the value of her relation with a gay male friend), and through doing so, to testify and represent. The locus of remembrance therefore coincides with the position of the everywoman whose life is, momentarily, turned upside down. Yet, rather than this widening access to the film's viewership, the effect is to funnel responses through a heteronormatively defined position, such that the roles and initiatives, community and experience of gay men affected by the AIDS crisis in France become mediated via their impact on familial structures of belonging.

\section{AIDS in French Cinema, before and after 2000}

Summarising representations of AIDS in French cinema before 2000, David Caron points out that the medium's collective nature and popular tendency have enabled film to capture and trace shifts in national perceptions and values since the $1980 \mathrm{~s} .{ }^{1}$ Identifying three successive periods in French AIDS cinema as "Les victimes innocentes ... et les autres"; "Une universalisation problématique"; and "Grand public et ouvertement gay", Caron's account situates films such as Mensonge (François Margolin, 1991), N'oublie pas que tu vas mourir (Xavier Beauvois, 1995 ) and Jeanne et le garçon formidable (Olivier Ducastel et Jacques Martineau, 1998) as epitomizing the considerable evolution of social attitudes, not only to HIV and AIDS as virus, condition and epidemic, but also to homosexuality and its place within the Republic over the same period. As Caron's chronology illustrates, the ongoing public narration of AIDS in France can be seen as paralleling a process of maturation in the normalisation of gay experience within the public - and Republican domain, culminating in Ducastel's and Martineau's depiction of a character, in Drôle de Félix (2000), who "happens to be" gay, HIV-positive and beur, without his identity or quest being defined restrictively by any one of these categories.

During the first decade of the twenty-first century, there has been an ostensible decrease in the public sense of urgency accompanying France's confrontation with

\footnotetext{
' David Caron, "Sida (au cinéma)", in Didier Eribon (dir.), Dictionnaire des cultures gay et lesbiennes (Paris: Larousse, 2003), pp. 433-435.
} 


\section{Murray Pratt}

AIDS. Other defining national crises have ousted this struggle from the media spotlight, yet as post-2000 messages from campaign groups such as Act Up-Paris make clear, there is a continued need for vigilance and a coherent politics of health in France and internationally, not least when messages about prevention and treatment strain to be heard in an era when "[1]e sida intéresse trop peu les décideurEs et les médias". ${ }^{2}$ Activists subsequently confront new challenges in their bids to maintain awareness and influence policy, chief among them the risk that HIV and AIDS fade from public attention, or be cast as a moment in history, as if the battle were already won. At the same time, with the establishment in 1999 of the PaCS (Pacte civile de solidarité) and other social advances, a sense that gay relationships have acquired an equal status with heterosexual ones, and that homosexuality has found a place within the universal Republican home, has, over the same period, come to lodge in the national consciousness. With this, however, comes a concern that the specificities of gay experience, history and ongoing inequities, for example in the field of adoption, are overlooked if not written out of a universalizing national picture. Significantly, in Drôle de Félix, the depiction of Félix's unproblematic relation to his sexuality, together with his management of his HIV status as an ongoing medical condition rather than an impending death sentence, are both in keeping with scientific advances in the treatment of the virus, and at the same time signal an attitudinal departure from what D.A. Miller describes as the mainstream cinematic spectacle of "gay men dying for us". ${ }^{3}$

In the light of these social changes, Caron's periodization of French AIDS cinema may require extension beyond 2000 to reflect these contextual shifts, and in particular to reflect the emergence of a historical understanding of AIDS, while remaining alert to its continuing relevance within a shifting sense of national sexual norms. As Richard Dyer explains in an argument that remains pertinent today, a key function of lesbian/gay cinema, as both politics and art, is to counter the risk of erasure with a "ceaseless construction, reconstruction and deconstruction of identities and cultures" producing the fictions we need, however imperfectly, to make sense of living in our time. ${ }^{4}$ Moreover, as Monica Pearl points out in her 2004 article on AIDS and New Queer Cinema, it is the disruption of identity, temporality and community, more than the subject matter, that marks the movement as a form of cinematic activism, especially in its engagement with "trying to interrogate, rewrite,

${ }^{2}$ Act Up-Paris website, posted 25 December 2006. http://www.actupparis.org/article2823. html. Accessed 1 November 2008. The word "décideurEs" appears in the original text, in line with one recent practice adopted by some French authors who wish to indicate the potential for both male and female occupancy of positions or roles.

${ }^{3}$ D.A. Miller, "On the Universality of Brokeback", Film Quarterly, 60, 3 (Spring 2007), 5060, p. 59.

${ }^{4}$ Richard Dyer, Now You See It: Studies on Lesbian and Gay Film (London: Routledge, 1990), pp. 285-286. 
and reassign responsibility". ${ }^{5}$ For Nick Rees-Roberts, an engagement with "local instances of sexual dissidence within their specific national formation" is therefore central to the identification of a French Queer Cinema, and his comprehensive account of the movement focuses on AIDS activism as one of the key vectors of contestation that differentiate his canon from a more "celebratory (white, middleclass), 'gay pride' rendition of French cinema". ${ }^{6}$ Making visible, retrieving that which might be lost, and the reinscription or retelling inherent in sexual dissident activism are thus central to French film's political role in figuring AIDS and its impact on gay experience.

\section{Commemoration and the familial frame}

As an act of reconstitution, Téchiné's film is positioned somewhere between a public act of remembrance and a personal testimony, both acknowledging the need for its audience to become aware of what, at the time, was only partially known, since - as Adrien comments - "Les gens ne savent pas que c'est la guerre", and conforming to a general requirement to personalize and colour the events of the mid-1980s within a domestic dramatization. On the one hand, an effect of Manu's death is measurable in the increasing radicalization of Adrien in the anti-AIDS movement. In this sense, it has the potential to enact a memorial to the early days of denial and mobilization documented by historians such as Frédéric Martel. However, the social fractures that characterized 1980s France and its awakening to the epidemic are still considered problematic by contemporary commentators, ${ }^{7}$ and the embedded presentations Adrien makes to conferences do little to capture the ideological struggles surrounding activists' early attempts to understand and combat the medical, political and social facts of the virus. On the other hand, the film advances a clearly familial habitus, setting up repeated scenes of the young couple nurturing or attending to their baby as an unremarked backdrop to key moments of dialogue, and epitomized by the oversized pink furry toy that Adrien, almost incidentally within the narrative progression, buys for the infant. By filtering the story of Manu's life and death predominantly through the relationship of a reproductive heterosexual couple, Les Témoins would seem to conform to the dominant prevention mindset of the era it revisits, with Sarah's intention to "témoigner son passage parmi nous" specifically echoing the problematic emphasis on grand public anti-communitarian messages

\footnotetext{
${ }^{5}$ Monica Pearl, "AIDS and the 'New Queer Cinema"', in Michelle Aaron, New Queer Cinema: A Critical Reader (Edinburgh: Edinburgh University Press, 2004), p. 24.

${ }^{6}$ Nick Rees-Roberts, French Queer Cinema (Edinburgh: Edinburgh University Press, 2008), p. 5.

${ }^{7}$ Frédéric Martel, Le rose et le noir: les homosexuels en France depuis 1968 (Paris: Broché, 1996). See also, however, Enda McCaffrey, The Gay Republic: Sexuality, Citizenship and Subversion in France (Aldershot: Ashgate, 2005), pp. 122 and 171, for a problematisation of the universalizing tendency of Martel's account.
} 


\section{Murray Pratt}

as evident in the slogan used in France at the time, "Le sida, nous sommes tous concernés". Questions about what is remembered, by whom and for whom, persist despite the film's democratic inclusion of a range of perspectives and attention to variant forms of male sexuality and desire.

As with any act of public commemoration, Téchiné's tribute to gay-specific experience of the early years of AIDS in France is filtered via a nationallyscaled version of normative conventions about what forms of experience have sufficient social capital to merit public remembrance. Self-aware of its potential for national commemoration through its inclusion, for example, of a clip of the 1984 Remembrance Day parade on television, Les Témoins builds on France's twenty-first century emphasis on recollecting other moments of trauma such as the Algerian War. In the process, the film risks falling into a trap identified by Pierre Nora in his account of the Age of Commemoration when he comments that "le véritable problème que pose aujourd'hui la sacralisation de la mémoire est de savoir comment, pourquoi, à quel moment le principe positif d'émancipation et de libération qui l'anime peut se retourner et devenir une forme d'enfermement, un motif d'exclusion, et une arme de guerre". ${ }^{8}$ As Nora points out, the acceleration of the past that commemoration entails, and its concomitant tendency to sacralise and bar access to the past, can be countered by the democratisation of history that is also implied. Opening spaces to enact collective and individual rememoration, Les Témoins could be seen as aiming to contest an official blindspot to the years of the epidemic, and national tendencies to foreclose the AIDS years as a moment in history, through Téchinés insistence on its impact on the many relational complexities it sets in motion. However, its focus on family as the public locus where value is ascribed and added points to a problematics of elision, erasure and empowerment that continue to structure available positions for gay male self-valuing within contemporary France. Nick Rees-Roberts points to a similar limitation to Les Témoins' considerable achievement in elaborating how forms of male intimacy elide normative positions, as well as the extent to which it captures aspects of AIDS' impact on gay male experience in the 1980s. Building on Bill Marshall's account of Téchiné's æuvre as eschewing militancy or any real sense of gay community, ${ }^{9}$ ReesRoberts positions Les Témoins as "an ultimately modest brand of queer cinema", a concern advanced even more forcefully, as Rees-Roberts points out, ${ }^{10}$ by activist Phillipe Mangeot, who critiques the film's redemptive teleology and inattention to the collective nature of early responses to AIDS. ${ }^{11}$

\footnotetext{
${ }^{8}$ Pierre Nora, "L'avènement mondial de la mémoire", originially published in Transit (2002), available online in Eurozine, http://www.eurozine.com/articles/2002-04-19-nora-fr.html. Accessed 1 November 2008.

${ }^{9}$ Bill Marshall, André Téchiné (Manchester: Manchester University Press, 2007).

${ }^{10}$ Rees-Roberts, pp. 122-124.

11 Philippe Mangeot, “Sida 2007-1984”, Cahiers du cinéma, 621 (March 2007), 27.
} 
Picking up Mangeot's twin critique, Rees-Roberts focuses on how the director's ethos of complex and plural cinematic structuration results in "the signification of Manu's death as a 'creative' gift to the surrounding witnesses" and a purview that restricts the founding of the AIDS activist movement to a moment of "singular agitation". ${ }^{12}$ In each case, I would contend, the film's ambition to represent an accessible yet nuanced historiography results in a tendency to play to a generalist, read hetero-defined, viewership, thus restricting its ability to queer its commemoration, in the sense that it might combat normative positions or serve as an advocate for activism itself. The third act of Les Témoins' triptych, concentrating on the effect of Manu's death, illustrates the extent to which the film is constrained by an ideology of family heteronormativity. In eliding the representation of the moment of Manu's death in favour of a visit by Adrien and Manu's sister, Julie, to his family home (and introducing for the first time their mother), the narrative unfolds according to a familiar logic found in Le Temps qui reste, whereby gay experience is reinstated within, its specificity erased in favour of, a conventional genealogy, a point reinforced by the fact that it is the sister rather than Adrien himself who is obliged to ask for a photo of Manu as a keepsake. Admittedly, Manu is permitted a moment to revoice his life as a gay man later in the film, when Sarah pauses on the coastal path to listen to his taped account of how he discovered the world of cruising. Again, though, the mediated framing of this episode contextualizes the experience as poignant, to be understood from her plenary enjoyment of her familiar landscape, through her relation to him, rather than something which has independent value.

Equally, the discovery during the visit to the mother's chalet that Manu's father was Algerian is also given no ideological weight, as is also the case regarding Mehdi's Maghreban heritage within the film's diegesis, in ways that are quite difficult to imagine as an accurate reflection of 1980s French attitudes. ${ }^{13}$ However, rather than standing as an aside, or creating further complexity to be debated within Téchiné's ongoing essay on masculine roles, this revelation serves no other purpose than to anchor the meanings of Manu's life choices and the impact of his death within familial trajectories. Sarah's own visit to her mother on the Mediterranean coast amplifies the model of lineage as determinant of value, when they are seen discussing the moment of her birth and what makes existence precious, while the mother plants shrubs in a scene that might have been drawn directly from Colette's life-affirming autobiography La Naissance du jour.

\footnotetext{
${ }^{12}$ Rees-Roberts, pp. 122-123.

${ }^{13}$ As commented by Rees-Roberts, pp.119-120, and Ginette Vincendeau, "A time to love and a time to die", Sight and Sound, 17, 11 (November 2007), 4647.
} 


\section{Remembering as erasure}

The dazzlingly complete light and vibrancy of the seascape where the group of friends assemble at the start and end of the film, the family idyll that Manu "passes" through, and that continues after his death, figure as the life drive that continues after his passage, and are in marked contrast to the film's few but significant night shots. The scenes showing Manu's first meeting with Adrien at a cruising ground, the visits made by his lovers during his seclusion in an out of season campsite, and his return to the scene of the initial encounter just before his death, are each shot in ways that prick the dark with isolated light spots, much like the film's reticence to illuminate the liaisons that take place there within anything other than the bigger, brighter picture of a heteronormed leisure world. It is this reluctance to figure a sense of either gay or activist community that constitutes the second limitation to Les Témoins' potential for bringing to the fore the queer history of AIDS activism or, it should also be pointed out, queering the retrospective vision of its contemporary viewers in ways that engage with current concerns about HIV in France, to the extent that the mediation of the story serves to close it off from the present, reinstated within familiar and familial terms, rather than resonating beyond the $1980 \mathrm{~s}$.

Ambivalences about demarcating the gay community (often masking a public incapacity for imagining gay men as autonomous or collective actors) that characterised French national responses to the epidemic have been well documented, ${ }^{14}$ and the film's demarcation of Adrien's professional and activist life from his place within the group of friends buys into this logic. Thus many of the doctor's encounters with Sarah and Mehdi take place as he is leaving work; his role in ensuring the couple's own HIV negative status following Manu's diagnosis is paramount and, importantly, it is only within the familial group they constitute that his personal trajectory is seen to be validated. There is scope, for example, for the film to focus on Adrien's own forms of grieving and their impact on his position within the medical establishment, as a way of understanding how this group in France first became sensibilised and militised by the epidemic. Alternatively, the complexity of his relationship with Manu offers, and in some ways exploits, potential for developing a contradictory and complex repertoire of loyalities and positions. However, neither of these strands is ever fully followed through, and each is cross-referenced to the drama of Sarah's and Mehdi's own personal development and their relationship with each other. After the death of Manu, the group of friends

${ }^{14}$ See, for example: David Caron, AIDS in French Culture: Social Ills, Literary Cures (Madison: University of Wisconsin Press, 2001); McCaffrey, The Gay Republic; and Murray Pratt, "AIDS Prevention, Gay Identity and National Homophobia in France", in Joe Andrew, Diana Holmes and Eva Kolinsky (eds), Why Europe?: Problems of Culture and Identity, volume 2: Gender, Youth and Education (London: Macmillan, St.Martin's Press, 2000), pp. 142-170. 
is joined at the same beach house setting where much of the drama of their relations was shot by a further "nouveau venu", Adrien's new American lover Steve, who holds out a different prospect for his partner. For, where Adrien's relationship with Manu was chaste, confrontational, contested, the scenes that show the new couple getting to know each other are erotically charged while also marked by tenderness and complicity. Rather than a closure, this relationship is framed as a personal evolution for Adrien, an opportunity for hope because of, rather than in spite of, his history. But this is an ending rather than a beginning, and by foreclosing with a shot of Sarah alone on the boat trip that ends the film, her companions off screen, it is made clear that it is also an aside. Téchiné's rememoration, in particular the film's framing of Manu's story through Sarah's recollection, effectively erases his "passage", from Adrien's affection, the group's collective memory, and our experience as viewers, as it recreates cyclically the earlier coastal idyll with the graft of a new replacement gay male character occupying his place. Neither Adrien nor Manu are afforded a community of belonging other than within this cycle, to the extent that the former's new relationship is only endorsed through the process of Steve's acceptance within the group.

What is ultimately missing from Téchinés tribute, in the erasure of gayspecific experience, collective activism, and recourse to redemption and poignancy, is a de-familialized structural sense of lineage capable of extending backwards as well as forwards. Without a way of making sense of forms of sexuality beyond the reproductive, coupled and family-sized group, the potential for activating testimony as queer critique or reattribution within film is hampered, all the more so when identification with gay characters, however pluralistically the mise en scène is handled, is brought back within the purview of straight sense-making. Turning to a moment of retroprojection from 1980s gay writing, itself meditating on how AIDS shapes the teleology of homosexual experience, a model for representing gay lives over time emerges that might be seen as offering an alternative approach to queer memory.

\section{Unfolding memory}

Writing in the postface to Guy Hocquenghem's anticipated memoirs (in reality, written as he faced his death in 1988, but published later, and articulated from the fabulated perspective of his survival to 2018 , and discussing a period of Hocquenghem's life almost 50 years prior to this point), René Scherer interrogates his friend's motivations in revisiting his youth, defining this as a process of "devenirenfant", a dissipation of the self in keeping with the writer's concern to avoid the assignations and fixities of identity. ${ }^{15}$ The processes of remembering and leaving

\footnotetext{
${ }^{15}$ Guy Hocquenghem, L'amphithéâtre des morts, afterword by René Scherer (Paris: Gallimard, 1994).
} 
a legacy, as he identifies them in Hocquenghem's text, ${ }^{16}$ can be considered less as the sacralisation and appropriation of the author's experience of AIDS, than an extension of the strategic exuberance and militancy that characterized his theoretical and fictional texts. What Scherer refers to as the biais in Hocquenghem's approach to the twin unsayables of AIDS and homosexuality, produces what he calls a textual fold, a "pli" that, in turn, "se déplie" and undoes the "repliement inconfortable dans la voiture familiale", ${ }^{17}$ generating in the process a potential for concealment as well as direct expression, an address that avoids the flattening out, or banalisation, of mediatised uniformity. For Scherer, the choice of an uncomfortable experience in the family car as an allegory to represent repressed childhood - here nodding to Hocquenghem's adequation of anti-homophobic struggle to the privatization of experience summed up by car ownership - enables a resexualisation of the social. For, rather than reinventing the closet, Scherer's fold is the start (or "devenir") of discursive possibility, a strategic refusal to be read literally, viewed and circumscribed unproblematically, there where socially sanctioned processes are wont to shepherd and confine any intervention into the pre-allocated and mass-constructed boxes of permissible identities. Queer avant la lettre, Hocquenghem's textual strategy (projecting his testimonial to a distant future when he can reposition his experience of illness beyond sensationalized stereotypes) and Scherer's intention in positioning his text in the terms of the fold, enact anticipated disruptions to the social fabric of recuperation and repression that each considers deleterious to equitable access to the plenitude and jouissance that life should be about.

There are aspects of Scherer's discussions of the politics and temporalities of both homosexuality and HIV/AIDS, not least his emphasis on a utopian, perhaps edenic, current of sexual liberation detectable in Hocquenghem's writing, that jar significantly with the anti-essentialising givens that inform much of contemporary queer theory. However, at the same time, the notion of folds in time capable of unsettling heteronormative recuperation offers a useful, and queerly strategic, model for thinking of processes of remembering and forgetting. Complementing more recent formulations of queer temporality such as Lee Edelman's No Future or Annamarie Jagose's Inconsequence, ${ }^{18}$ and their refusals of straight paradigms of sequentiality, hierarchy and futurity as the measures and summa of discursive and social value, Scherer's temporal fold might offer the possibility of relocating the natural, dominant or officially ascribed motivations behind acts of group commemoration, remembering to forget, as it were, the logics of the heteronormative. For within the rush to sign and seal commemoration of the AIDS

${ }^{16}$ Scherer, p. 145.

${ }^{17}$ Scherer, p. 139

18 Annamarie Jagose, Inconsequence: Lesbian Representation and the Logic of Sexual Sequence (Ithaca: Cornell University Press, 2002); Lee Edelman, No Future: Queer Theory and the Death Drive (Durham: Duke University Press, 2004). 
epidemic, there is a danger in lodging queer consciousness too exclusively in the past, since "[i]ncreasingly, homosexuality is confined to the mnemic register, its surfacing in the present a temporary glitch in that future-directed temporality that is $[\ldots]$ contracted to heterosexuality". ${ }^{19}$

As with Hocquenghem's fictionalized memoirs, there is perhaps some scope for reviewing Les Témoins in terms of its introduction of folds in the temporality of remembering and forgetting that disrupt dominant narrative sequencings brought to bear on homosexuality and AIDS and their recuperation within a normative value set. For, rather than producing an officially sanctioned commemoration, Téchiné has exploited film's inherent schism between narrative and representation to activate competing vectors of remembering and forgetting as a complex and continuing field of desire, with the potential to resonate into the present and beyond. Through the folds of belonging that brought him into close contact with Mehdi and Sarah, and by dint of his impact on Adrien's engagement with AIDS activism, it could be argued that Manu's life was not forgotten, but instead reverbated across social and sexual barriers, affected all the film's characters, and by extension, all of France. Activism, grief, conflict and desire, rather than separated out and unproblematic in their telling, might thus be thought of as emerging within the film as relational and mutually constitutive; and it is through tracing their folds and entanglements that they can be understood and contextualized. Yet, to do so would run counter to the ways that the affective experience of viewing Les Témoins, like a spectrum in reverse, gathers the diffracted histories of its protagonists into a single narrative retrospection.

\section{Conclusion}

Perhaps it is too much to ask of a general release film about AIDS to bridge the generic divide and embrace tactics of disruption deployed in the more shadowy realms of the fictional literary memoir. However, the modesty of Téchinés queer cinema noted by Rees-Roberts ought nonetheless to be held to further account, particularly the implications of structuring his attempt at commemorating AIDS in France through a universalizing framework of witnessing. All were not and are not equally affected, and to forget the ways that living with AIDS transformed and continues to transform the lives of gay men, and other groups that also remain insufficiently demarcated within Republican paradigms, is to do a disservice not only to their experiences but to the acts of resistance and imagination with which they responded. Released in the same year as Jacques Nolot's Avant que j'oublie and following François Ozon's Le Temps qui reste (2005), to cite two further examples of post-2000 French AIDS cinema, Les Témoins could be seen as belonging to a new period, one of irresolution, parenthesis and revisionism. However, even within

${ }^{19}$ Jagose, p. 82. 
this relatively limited canon, different nuances, emphases and possibilities can be discerned.

Considered alongside Nolot's account of a middle-aged gay man's difficulty in establishing community or affection as he decides on whether to begin tritherapy treatment, and Ozon's depiction of a gay man's increasing isolation as he confronts a fatal diagnosis of cancer, Téchiné's essay in testimony points to cinema's hesitation in knowing how to move beyond what Caron identifies as the "Grand public et ouvertement gay" period. In the 2005 instance, Ozon's narrative, with his character's future-oriented decision to father a baby to a childless couple and his retrospective embrace of his own boyhood, appears to be as implicated as Les Témoins in a need to circumscribe gay experience within a normative heterosexual frame of reference. Moreover, by explicitly eliding AIDS from the film's sphere of engagement from the moment of diagnosis - the progatonist, Romain, is told by the doctor, "Non, le sida, ça n'a rien à voir" - Ozon effectively situates his meditation on the value of a young gay male life within a dissonant teleology that is unable to take account of the ways in which homosexual experience in contemporary France has been, and continues to be, shaped by personal and political reactions to the virus and its centrality in sexual and social activity. Romain's journey, as much as that undertaken by Manu decades before, proceeds within an affective landscape delimited by cultural barriers in imagining how to value the ties and relationships established by gay men other than through a family-normative lens.

While Avant que j'oublie eschews this trajectory, Nolot's performance of the abandoned gigolo alternates between reliving the sexual and social belonging of his pre-AIDS years, and inventing roles that make his age, condition, sexuality and health inhabitable. Significantly, and in contradistinction to the increasingly limited social, sexual and financial opportunities that mark his day to day life, it is his work as a writer that enables him to untangle and understand how he got to where he is now, and how he can move on. That Nolot's cinematic achievement, through refraining from tying up and shutting down the episodicity and refractedness of the protagonist's past and present, can unfold a querying, uncertain yet productive texture hints that remembering and forgetting can, in film as in literature, reverberate beyond restrictive social structures. Dragged up at the request of his own rent boy and visiting a porn cinema, Nolot's closing scenes show his character, accompanied by the melodramatic soundtrack from the theatre, slowly take cognizance of his position within space and time, gradually realize what it means to make his performance his own, turn, and walk back out of shot.

Being in time requires realization and awareness beyond the simple process of remembering, and all the more so when temporal value itself is ascribed within heteronormative structures of family, marriage, inheritance, coming of age. As with the notion of the folds in time Scherer discovers in Hocquenghem's prose, unravelling the implications of queer history requires not erasure or evenhandedness, but a to and fro over time that worries away at, rather than leaves 
hanging, the question Adrien asks Sarah towards the end of Les Témoins about whether gays and straights are really meant to be together. Rather than working to disrupt the heterosexualizing screen of mainstream cinema, then, or querying the ways in which attitudes, relations and values in France have been shaken up by the social and cultural shifts occasioned by the AIDS crisis, Les Témoins ultimately takes only a hesitant a step forward to the past. In doing so, it avoids unsettling fixed assumptions about the French viewing body, how it might have evolved after more than twenty years of living with HIV/AIDS, and whether the constitutive memories and desires, values and experiences of that body are universal, unproblematic or sufficient. 